\title{
Anesthetic management in VACTERL syndrome
}

\section{VACTERL sendromunda anestetik yaklaşım}

Illker Öngüç Aycan ${ }^{1}$, Hüseyin Turgutt2 ${ }^{2}$ Zeynep Baysal Yıldırım¹ ${ }^{1}$ Gönül Ölmez Kavak ${ }^{1}$

\begin{abstract}
VACTERL Syndrome consists of many problems regarding to anesthesia management due to multiple congenital malformations which may include vertebral, cardiac, trachea-osephageal, renal and limb anomalies. Here we present our anesthetic management -in terms of preanesthetic evaluation, premedication, induction and maintenance of anesthesia and postoperative follow up- in a newborn patient with VACTERL Syndrome undergoing tracheo-eosophagial fistula operations. J Clin Exp Invest 2014; 5 (1): 103-105
\end{abstract}

Key words: VACTERL syndrome, anesthesia, ketamin

\section{INTRODUCTION}

VACTERL syndrome contains vertebral defects $(v)$, anal atresia $(A)$, cardiac defects $(C)$, tracheoesophageal fistula (TE), renal malformations (R), and limb abnormalities (L). All major malformations in acronym is not necessary to diagnose a newborn's VACTERL syndrome. At least three of these congenital malformations provide the diagnosis of the VACTERL syndrome [1-3]. Due to multiple congenital anomalies of different systems, anesthesia management of these patients can be complicated. In this case report, we present our anesthetic experience in a newborn with VACTERL syndrome operated due to tracheo-esophageal fistula.

\section{CASE REPORT}

A newborn male infant weighted 2300 gram was born by caesarean section and there was no relationship between his parents. Newborn's operation was immediately planned due to tracheo-eosophagial fistula. VACTERYL syndrome was diagnosed in our patient because of tracheosophageal fistula,

\section{ÖZET}

Çoklu konjenital malformasyonlardan dolayı VACTERL sendromunda anestezi yönetimi vertebra, kardiyak, trakea-özefageal, renal ve ekstremite anomalileri nedeniyle bir çok problemi içermektedir. Bu yazıda trakeo-özefageal fistül nedeniyle opere olan VACTERL sendromlu hastamızdaki anestezi öncesi değerlendirme, premedikasyon, anestezi indüksiyonu ve devamı ile postoperatif izlemi içeren anestezi yönetimimizi sunmayı amaçladık.

Anahtar kelimeler: VACTERL sendromu, anestezi, ketamin

esophagus atresia, pes equinovarus and posterior uretral valve patterns.

Before operation, cystostomy was opened due to posterior urethral valve. Preoperative examination was normal except rhonchus findings in chest oscultation. Laboratory evaluation revealed BUN: $17 \mathrm{mg} / \mathrm{dL}$, creatinine: $0,7 \mathrm{mg} / \mathrm{dL}$, glucose: $62 \mathrm{mg} /$ $\mathrm{dL}$, potassium: 3,1 mmol.dL-1, Na: $141 \mathrm{mg} . \mathrm{dL}-1$, calcium: 8,5 mg.dL-1, AST: 78 U.L-1, ALT: 7 U.L-1, total protein: 5,5 g.dL-1, albumine: 2,7 g.dL-1, bilirubin: $3,2 \mathrm{mg} . \mathrm{dL}-1$, indirect bilirubin: $2,9 \mathrm{mg} \cdot \mathrm{dL}-1$, WBC: 11,9 K.UL-1, hemoglobin: 18,4 g.dL-1, hematocrit: $50 \%$, platelet: 328 K.UL-1, International Normalized Ratio (INR): 1,22, activated partial thromboplastin time (aPTT): 49,8 seconds and because of the fact that disordered coagulation parameters, $46 \mathrm{cc}$ fresh frozen plasma was given. Control values was INR: 1,05, aPTT: 28 seconds. The patient was operated after giving 184 cc.24hour-1 $1 / 3$ izodeks (Eczacıbaşı-Baxter $囚$, İstanbul) and $9.6 \mathrm{cc}$. 24 hour-1 total parenteral nutritional support. Antibiotic therapy was administered by giving $35 \mathrm{mg}$ amicasin once a day and $55 \mathrm{mg}$ ampicillin twice a

${ }^{1}$ Dicle University, Faculty of Medicine, Department of Anesthesiology and Reanimation, Diyarbakır, Turkey

${ }^{2}$ Women Health and Gynocology Hospital, Diyarbakır, Turkey

Correspondence: Illker Öngüç Aycan,

Dicle University Faculty of Medicine, Dept. Anesthesiology and Reanimation, Diyarbakır, Turkey Email: ilker-aycan@gmail.com Received: 16.09.2013, Accepted: 04.11.2013

Copyright (C) JCEI / Journal of Clinical and Experimental Investigations 2014, All rights reserved 
day. Patient was operated at 24th hour of caesarean section. Standard anesthesia monitorization (three lead electrocardiography (EKG), $\mathrm{SpO}_{2}$, heat, non-invasive blood pressure (NIBP)) was applied to patient. It was seen that $\mathrm{SpO}_{2}$ was \%65, heart rate was 130 beats.min-1, NIBP was $67 / 34 \mathrm{~mm} . \mathrm{Hg}-1$. Patient had multiple organ anomaly. Premedication was done by giving $100 \mu \mathrm{g}$ atropin after then anesthesia induction was done by giving 2 mg.kg-1 ketamine, 0,1 mg.kg-1 midazolam. Rocuronium 0.5 $\mathrm{mg} / \mathrm{kg}$ was used in order to achieve rapid intubation with minimal mask ventilation.

Following anesthesia induction patient was intubated with 3.0 number endotracheal tube by the expert anesthetist. Ventilation was maintained with pressure support mode, respiration rate was 50 breath.min-1 and airway pressure was set at $15 \mathrm{~cm}$ $\mathrm{H}_{2} \mathrm{O}$. Anesthesia was maintained with $0,75 \mathrm{mg} \cdot \mathrm{kg}-1$ iv bolus ketamine in every 30 minutes and \%60-40 $\mathrm{O}_{2}$-air gas mixture. During the operation, $\mathrm{SpO}_{2}$ was between $95-100 \%$, heart rate was between 100120 beats.min-1, NIBP was between 59/27-71/35 $\mathrm{mmHg}$, and etCO $\mathrm{C}_{2}$ was between $36-55 \mathrm{mmHg}$. Operation was ended in 130 minutes. After 10 minutes from the end of the operation, spontaneous respiration began and patient was monitored in spontaneous mode. The patient's $\mathrm{SpO}_{2}$ was between 93$95 \%$ with $60-40 \% \mathrm{O}_{2}$-air gas mixture. However, the patient was not extubated due to the decrease of saturation in room air.

Patient transferred to the neonatal intensive care unit as intubated. In postoperative second day patient was ventilated with pressure support mode followed by t tube technic. At postoperative third day all pharyngeal reflexes was fully reversed, adequate spontaneous breathing effort was established and the patient was extubated uneventfully. Postoperative $4^{\text {th }}$ day patient was sent to service and patient was discharged at postoperative $7^{\text {th }}$ day.

\section{DISCUSSION}

Patients with VACTERL syndrome have a combination of many different repeated operations thanks to having many anomalies. Patients' prognosis becomes better with advances in surgical techniques [1]. However, VACTERL syndrome has risk in terms of anaesthesia due to having many anomalies. The risk of aspiration increases in VACTERL patients depending on regurgitation and tracheo-eosophagial fistula [4]. In order to prevent regurgitation and aspiration we made premedication with atropine, fast induction and intubation with rocuronium. The induction method which we used is correlated with methods used in previous reports.

There have been reported no difference between inhaled anesthetic agents in literature. Khatavkar [4] reported that 8-year-old patient with VACTERL syndrome who had been operated more than one was operated for cataract surgery and given halothane Mariano and his friends [5] informed in their case report that a newborn baby was operated due to VACTERL syndrome and isoflurane was used in anesthesia. Also, Yıldız and et all [2] used sevoflurane to patient with VACTERL syndrome. We prefer intravenous anesthesia with ketamine combined with atropine premedication in order to prevent laryngoscopy induced vagal stimulation and bradycardia which had been showed an effective method in newborns by Barois et all [6]. Barois et all showed that immediate ketamine analgesia plus atropine for tracheal intubation was effective in terms of decreasing pain and preventing vagal stimulation induced bradycardia. Also we used atropine premedication before induction in order to prevent ketamine induced hipersalivation.

Cardiac malformations have been reported in approximately $40-80 \%$ of patients with VACTERL association [7]. The most common cardiac anomaly in VACTERL syndrome is ventricular septal defect $22.3 \%$ [8]. Patients may also present with Tetralogy of Fallot, patent ductus arteriousus and atrial septal defect [8]. In our patient there was no cardiac anomaly and patient was haemodinamically stable during operation.

As findings are so variable in patients with VACTERL syndrome, each patient be carefully evaluated individually and anesthetic approach should be preferred according to the patient.

Our patient has no cardiac anomaly which might complicate our anesthesia management however we take all cautions in order to prevent possible hemodynamical disturbances, risk of regurgitation and aspiration. According to our experience we can conclude that anaesthesiologist should prefer anesthesia management according to patient health conditions, risk factors and type of surgical treatment. Close monitorization is also crucial in perioperative and postoperative periods.

\section{REFERENCES}

1. Solomon BD. VACTERL/VATER association. Orphanet 2011;6:1-12.

2. Yıldız TŞ, Özcan D, Solak M, Toker K. VACTERL Syndrome and Anesthesia. J Anesth 2012;20:174-175. 
3. Luce V, Mercier FJ, Benhamou D. Anesthetic management for a parturient affected by the VACTERL association. Anesth Analg 2004;98:870-878.

4. Khatavkar SS, Jagtap SR. Anaesthetic management of cataract surgery in VACTERL syndrome case report. Indian J Anaesth 2009;53:94-97.

5. Mariano ER, Chu LF, Albanese CT, Ramamoorthy C. Successful thoracoscopic repair of esophageal atresia with tracheoesophageal fistula in a newborn with single ventricle physiology. Anesth Analg 2005;101:1000-1002.
6. Barois J, Tourneux P. Ketamine and atropine decrease pain for preterm newborn tracheal intubation in the delivery room: an observational pilot study. Acta Paediatr 2013 Sep 10. doi: 10.1111/apa.12413.

7. Rittler M, Paz JE, Castilla EE. VACTERL association, epidemiologic definition and delineation. Am J Med Genet 1996;63:529-536.

8. Hatemi AC, Gursoy M, Ceviker K, et al. Ventricular septal defect closure in a patient with VACTERL Syndrome: anticipating sequelae in a rare genetic disorder. Tex Heart Inst J 2008;32: 203-205. 